\title{
Cross border tourism in Nigeria border state and its socio-economic impact on development
}

\author{
Omolomo Odunayo Tobora \\ Faculty of Economics and Business, Univerisiti of Malaysia, Sarawak, Malaysia \\ Email address: odunayophd@yahoo.ca
}

\begin{abstract}
Tourism is very vibrant sector in the world economy apart from contributing significantly to the Gross domestic product (GDP) of many countries, it provides employment for a huge percentage of the world populate. Cross boarder tourism can be defined as the activities of persons traveling across the broader to stay in places outside their usual environment for a reasonable period of time. The objective of this paper is to examine impact of socio-economic of tourism in Lagos Simple random sampling technique will be use in the selection of respondents qualitative interview method will be adopted. Data will be analyzed using percentile and chi-square. The study revealed among other things that tourism had been found to a great player in the economy an endowed nation. Essentially, the study discovered that the nation stand to gain economically from this sector if it is properly developed. In the conclusion, I will present research approach employed for validating conceptual research framework.
\end{abstract}

Keywords: Tourism; GDP; cross border; socio-economic; travelling

\section{INTRODUCTION}

Tourism is a fast growing economic activity in many countries around the world and its plays an important role in the economic and technological development of the nations, According to (Omotayo 2000) tourism serves to stimulate the development of basic infrastructure, contributes to the growth of domestic industries, attracts foreign investment and facilities the transfer of technology and information. (Ackoff, 1974) which cut across fields of expertise and administrative boundaries and, seemingly, become connected with almost everything else. It also, in an archetypal Leiper form, raises issues of measurement and analysis for models that measure the tourism economy in different locations because the partial industrialization hypothesis identifies the potential grey areas of research and measurement that many researchers simply assume either do not exist or assume away.

The world Travel and Tourism Council(WTTC) estimated that tourism is the largest industry (Coles 2006) Tourism is said to directly and indirectly generates and supports 204 million jobs. This is equivalent to more than $10 \%$ of the world workforce and its forecast to rise to over $11 \%$ of manpower in the early years of the twenty first century. However, there are many other organizations such as food suppliers, petrol stations, and retailers, sometimes described as 'allied industries', which also benefit from tourists but which are not readily identified as part of the tourism industry. 
Therefore, in most circumstances, businesses which regard themselves as non-tourism businesses will often not create linkages with tourism businesses for regional promotion unless there is a clear financial reward. It will often require an external inducement, such as promotion schemes established by government at no or minimal cost to individual businesses, or regulatory action such as compulsory business rating tax for promotion purposes, before linkages can be established (Hall \&Jenkins, 1995; Hall, 1999; Jenkins, 2000). In public policy terms Hall and Jenkins (1995), Dredge and Jenkins (2007) and Hall (2008) have therefore argued that the partially industrialized nature of tourism means that tourism, like the environment, should be regarded as a meta-problem which represent highly interconnected promotional, planning and policy. Tourism is also responsible for over $10 \%$ of Global Gross Domestic Product (GDP) a figure that is forecast to rise over $11 \%$ early in the twenty-first century (Copper and Hall1998). In the united States of America (U.S.A) where tourism is ranked high in the Gross Domestic Product (GDP) the Travel Industry Association of America (TIAA) has it that total travel expenditure in the U.S.A by both domestic and international travelers increased by $64 \%$ from $\$ 343.9$ billion to $\$ 563.6$ billion in 2000 .

Despite the weakening of trades in that country in 2001 due to September 11 attack, travel and tourism continued to makeup the largest retail in the U.S shopping has been identified as the number one activity by tourists, while outdoor activities rank second and visiting museums and historical places was in the third rank. Travel and Tourism continue to be important engines of employment directly getting 11 million jobs and $\$ 165.8$ billion in payroll in 2001 while supporting another 10 million people indirectly, in addition, travel and tourism are a significant source of tax revenue for the regional and national governments. in 2001 it is estimated that the U.S tourism industry directly generated nearly $\$ 94.4$ billion in tax revenue for federal, state and local governments. According to the (WTTC report 1995) the total impact on the economy of U.S was $\$ 1,153.26$ billion in 2001, an amount which almost equal Nigeria national budget tourism contributed $13 \%$ ( $\$ 63.79$ billion U.S dollars) to Canadian Gross Domestic Product (GDP) in 1988 and $14.7 \%$ (or \$1.8 million on payroll ) of its total employment in 1988 (WTTC report 1995).

In Africa, the size of the tourism industry is about $\$ 28.7$ million with a net income value of 12 billion U.S dollars contributing about $8 \%$ of the Gross Domestic Product (GDP) South Africa is one of the highest tourism destinations in this continent with a size of 6.5 millions square miles, a value of R53.2 billon as income providing about 1.1 million employment and a G.D.P contribution of $10 \%$ which is equivalent to $\$ 2.7$ billion.

Table 1. MasterCard Worldwide Insight 2013 The world's Top 15 Cross-Border Country.

\begin{tabular}{|c|c|c|c|c|}
\hline \multirow{2}{*}{ Rank } & \multirow{2}{*}{ Destination City } & \multirow{2}{*}{ Market } & \multicolumn{2}{|c|}{ Visitor Spend (US Billion) } \\
\cline { 4 - 5 } & & & $\mathbf{2 0 1 2}$ & $\begin{array}{c}\text { \% Growth 2011 } \\
\mathbf{2} 2012\end{array}$ \\
\hline 1 & London & United Kingdom & $\$ 21.1$ & $10.3 \%$ \\
\hline 2 & Paris & France & $\$ 17.8$ & $1.5 \%$ \\
\hline 3 & Bangkok & Thailand & $\$ 19.3$ & $16.6 \%$ \\
\hline 4 & Singapore & Singapore & $\$ 12.7$ & $12.7 \%$ \\
\hline
\end{tabular}




\begin{tabular}{|c|c|c|c|c|}
\hline 5 & Istanbul & Turkey & $\$ 10.6$ & $20.7 \%$ \\
\hline 6 & Hong Kong & SAR(China) & $\$ 9.5$ & 9.5 \\
\hline 7 & Madrid & Spain & $\$ 11.5$ & $-0.8 \%$ \\
\hline 8 & Dubai & UAE & $\$ 18.8$ & $9 \%$ \\
\hline 9 & Frankfurt & Germany & $\$ 8.1$ & $9.6 \%$ \\
\hline 10 & Kuala Lumpur & Malaysia & $\$ 13.7$ & $13.7 \%$ \\
\hline 11 & Seoul & South Korea & $\$ 7.7$ & $8.0 \%$ \\
\hline 12 & Rome & Italy & $\$ 7.8$ & $2.9 \%$ \\
\hline 13 & New York & USA & $\$ 19.4$ & $7.2 \%$ \\
\hline 14 & Abu Dhabi & UEA & $\$ 2.7$ & $2.7 \%$ \\
\hline 15 & Barcelona & Spain & $\$ 7.3$ & $7.0 \%$ \\
\hline
\end{tabular}

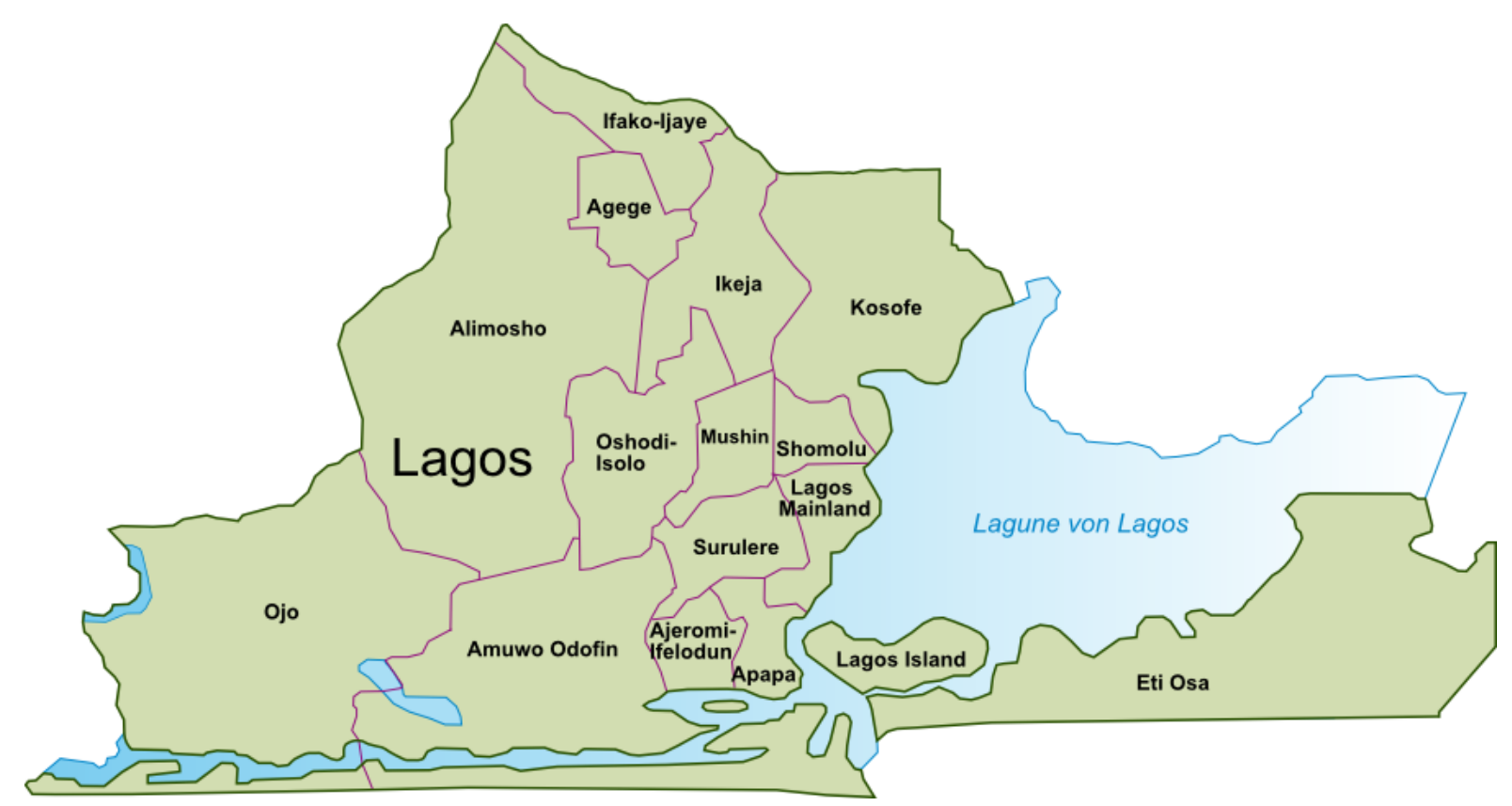

Figure 1. GIS map showing Lagos State and all the local government.

The important of tourism to the Nigeria economy can never be over emphasized although, there exist a famine of tourism statistics due to the non-chalant attitudes of successive administrations towards the development of tourism in Nigeria. Tourism has however contributed its quota to the Nigerian economy despite the dearth of investment in the sector. The service sector of the economy of which tourism and travel related industry have a large share which have contributed $31.7 \%$ to Nigeria G.D.P, a large number of people also derive their living from this neglected sector, considering the importance of tourism to an economy. This sector contribute to socio-economy development and it's also contribute to 
foreign exchange earnings or income and employment generation has been largely ignored (Harrison 1992) which made this study a worth venture it is hope that the result of this research will provide evidence to the socio-economic benefits of tourism vis-a vis the negative effects. This will form the basis for effective development of this sector to enhance its contribution to general well being of the society.

\section{LITERATURE REVIEW AND THEORTICAL FRAMEWORK}

Tourism is a collection of activities, services and industries that delivers a travel experience, including transportation, accommodations, eating and drinking establishments, retail shops, entertainment businesses, activity facilities and other hospitality services provided for individuals or groups traveling away from home. Tourism is a social, cultural and economic phenomenon which entails the movement of people to countries or places outside their usual environment for personal or business/professional purposes. These people are called visitors (which may be either tourists or excursionists; residents or non-residents) and tourism has to do with their activities, some of which imply tourism expenditure (W.T.O 2000). As such tourism has implications on the economy, on the natural and built environment, on the local population at the destination and on the tourists themselves. Due to these multiple impacts, the wide range and variety of production factors required to produce those goods and services acquired by visitors, and the wide spectrum of stakeholders involved or affected by tourism, there is a need for a holistic approach to tourism development, management and monitoring. This approach is strongly recommended in order to formulate and implement national and local tourism policies as well as the necessary international agreements or other processes in respect of tourism.

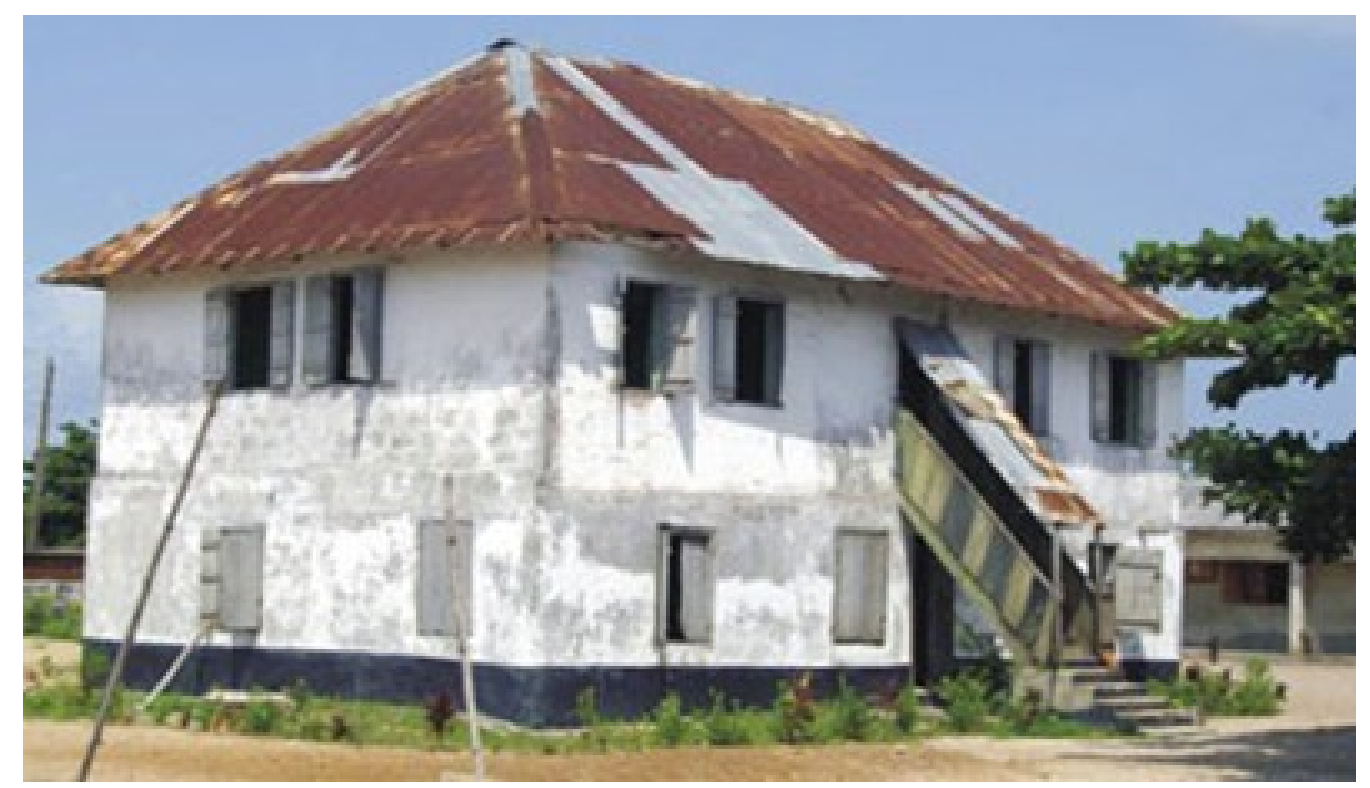

Figure 2. The first storey building in Nigeria, which was built in 1845 in Badagry Lagos State.

According to (Leiper 1989) tourism is "the sum of the phenomena and relationships arising from the interaction of tourists, business suppliers, host governments and host communities in the process of attracting and hosting these tourists and other visitors. 


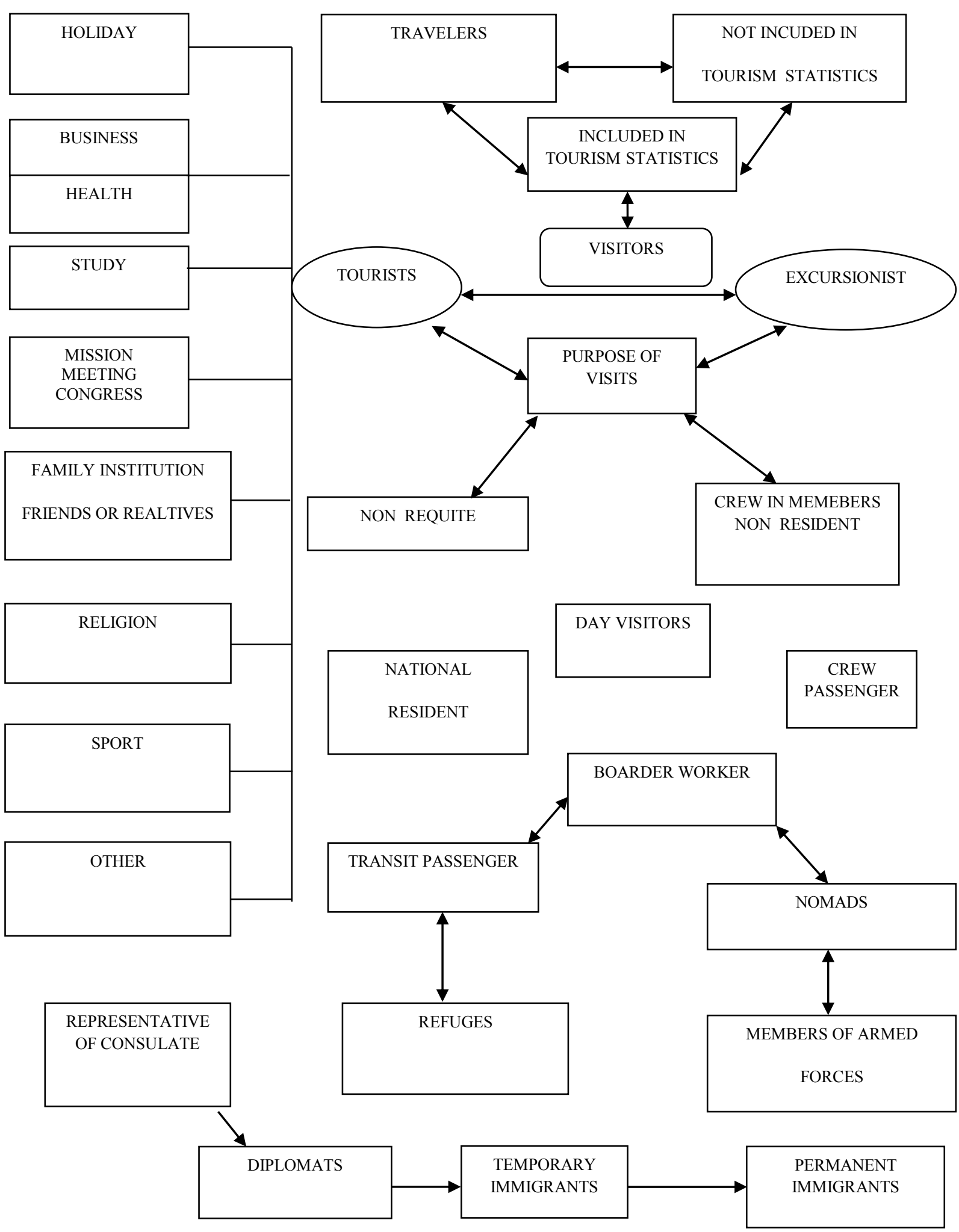

Figure 3. Source J. Christopher 1988.

Other terms of interest are: Excursionist: Persons traveling for pleasure in a period less than 24 hours (Leiper and Goeldner, 1986). Foreign Tourist: Any person visiting a country, other than that in which he/she usually resides, for a period of at least 24 hours (Committee of 
Statistical Experts of the League of Nations, 1937). Travel: The act of moving outside one's home community for business or pleasure but not for commuting or traveling to or from school (Smith, 1991). Visitor: Any person visiting a country other than that in which he/she has his/her usual place of residence, for any reason other than following an occupation remunerated from within the country visited (United Nations Conference on International Travel and Tourism, 1963).

\section{DEMAND SIDE OF TOURISM}

Tourism has a demand side (DS) and a supply side which differs from that of that whole economy in two majors ways Firstly, tourism cannot be defined and measured from supply side independent of its demand side. The supply of tourism is defined by its demand in the sense that tourism demand define first and then used as a guide for identifying its supplies, secondly, tourism final demand does not equal the value added generated by tourism suppliers in the process of supplying to tourism final demand the (WTO) proposed that tourism could be measured from both the demand side and supply despite these differences. Tourism is measured from the demand side by tourism expenditures on goods. According to (WTO) tourism expenditure made by a visitor or on behalf of a visitor for and during his/her trip and stay at destination.

\section{SUPPLY SIDE}

Defining tourism from the supply side involve attempts to view activities generated at destination by the existence of tourism demands. According to (Smith 1999) there are two basic approaches to defining the tourism sector conceptual, descriptive and technical. (Leper 1979) Suggested the supply side from conceptual point of view; the tourism industry consists of all those firms, organizational and facilities which are intended to serve the specific needs and wants of tourists. The technical supply side definitions has a major problem which lies in the facts there is a spectrum of tourism business, from those who are wholly serving tourists to those who also serve local residents and other markets. A solution to this problem is found in the classification of business into two types.

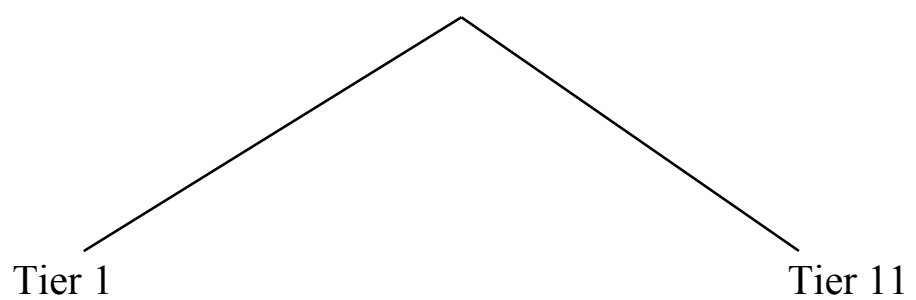

Business that would not survive without tourism
Business that could survive without tourism in diminished form 
According to (Smith 1991) is consistent with other industrial sectors it allows the size of the tourism industry to be judge using standard industrial classification (SIC) an important development as there is no (SIC) for tourism, which was developed into a Standard International Classification of Tourism activities (SICTA).

Table 2. World tourism organization classification on tourism.

\begin{tabular}{|c|c|c|}
\hline ISIC Divisions & Business Activity & Example \\
\hline Construction & $\mathrm{T}$ & $\begin{array}{l}\text { Hotels, Recreational facilities, } \\
\text { Transport facilities, Resort Residence }\end{array}$ \\
\hline $\begin{array}{l}\text { Wholesale and } \\
\text { Retail }\end{array}$ & $\mathrm{P}$ & $\begin{array}{l}\text { Motor vehicles sales, Vehicle fuels, } \\
\text { Retail sales of Textiles }\end{array}$ \\
\hline $\begin{array}{l}\text { Hotels and } \\
\text { Restaurants }\end{array}$ & $\mathrm{P}$ & Fast food Restaurants, Food \\
\hline \multirow{2}{*}{$\begin{array}{c}\text { Transport } \\
\text { Storage } \\
\& \\
\text { Communications }\end{array}$} & $\mathrm{P}$ & $\begin{array}{c}\text { Transport via railways, chauffeured } \\
\text { vehicles, inland water ways }\end{array}$ \\
\hline & $\mathrm{T}$ & $\begin{array}{l}\text { Airlines, Cruise ship, Tour buses, Long } \\
\text { distance Buses }\end{array}$ \\
\hline \multirow{2}{*}{$\begin{array}{l}\text { Financial } \\
\text { Intermediation }\end{array}$} & $\mathrm{P}$ & $\begin{array}{c}\text { Exchange of currency, Life insurance, } \\
\text { credit Cards }\end{array}$ \\
\hline & $\mathrm{T}$ & Travel Insurance \\
\hline \multirow{2}{*}{$\begin{array}{l}\text { Real Estate } \\
\text { and Renting }\end{array}$} & $\mathrm{P}$ & $\begin{array}{l}\text { Buying or Selling of leased Property, } \\
\text { Letting or owning of leased property }\end{array}$ \\
\hline & $\mathrm{T}$ & $\begin{array}{l}\text { Rental of ski equipment, letting of } \\
\text { owned tourism property }\end{array}$ \\
\hline \multirow{2}{*}{$\begin{array}{c}\text { Public } \\
\text { Administration }\end{array}$} & $\mathrm{P}$ & $\begin{array}{l}\text { Translation services, customs } \\
\text { administration, fishing regulations, } \\
\text { Foreign affairs, Border Guards }\end{array}$ \\
\hline & $\mathrm{T}$ & $\begin{array}{c}\text { Tourism administration, information } \\
\text { Bureau, Visa insurance, Regulations of } \\
\text { private transport }\end{array}$ \\
\hline \multirow[b]{2}{*}{ Education } & $\mathrm{P}$ & $\begin{array}{l}\text { Adult education, Driving schools, } \\
\text { Flying schools and boating Instrument }\end{array}$ \\
\hline & $\mathrm{T}$ & $\begin{array}{c}\text { Hotels, schools, tourism education } \\
\text { programmes, reaction and park } \\
\text { services }\end{array}$ \\
\hline \multirow[t]{2}{*}{ Other Community } & $\mathrm{P}$ & $\begin{array}{c}\text { Swimming, Scuba instruction, Flying } \\
\text { instruction, Boating instruction, and } \\
\text { entertainment }\end{array}$ \\
\hline & $\mathrm{T}$ & $\begin{array}{c}\text { Travel Club, Visitors Bureau, Travel } \\
\text { unions. }\end{array}$ \\
\hline \multirow[t]{2}{*}{$\begin{array}{c}\text { Extra Territorial } \\
\text { Organization }\end{array}$} & $\mathrm{P}$ & $\begin{array}{l}\text { WTO, OECD, World Bank, IMF, } \\
\text { ASEAN }\end{array}$ \\
\hline & $\mathrm{T}$ & International Tourism bodies \\
\hline
\end{tabular}




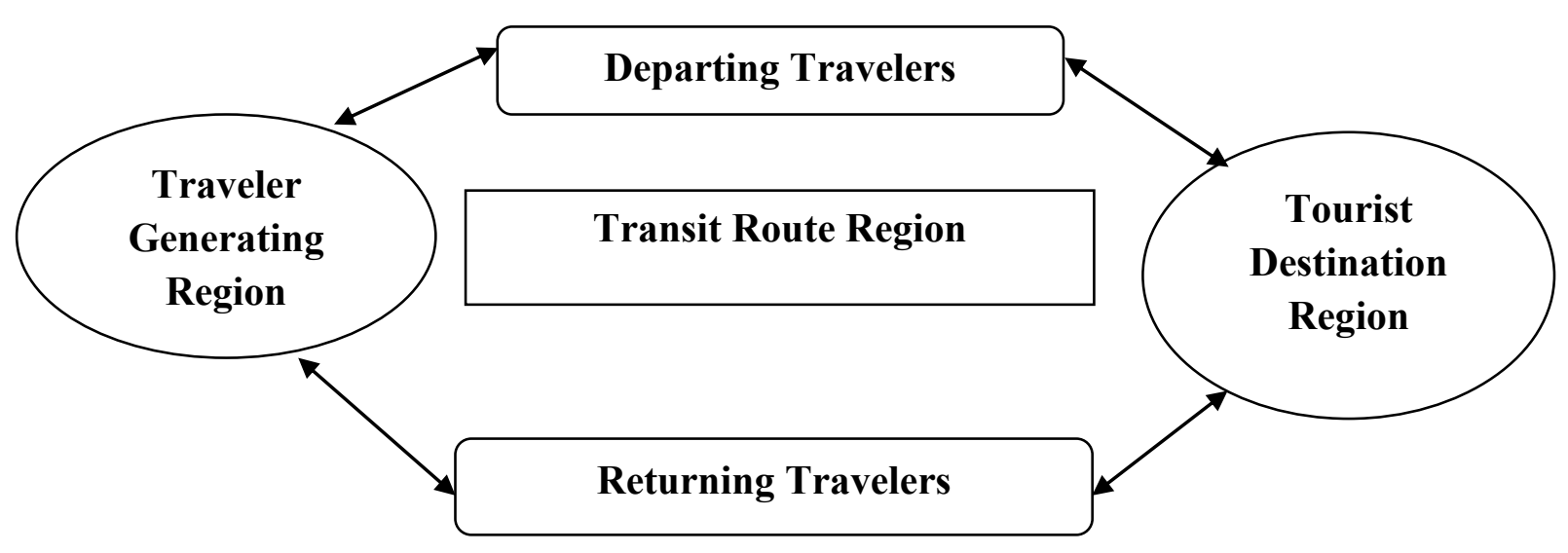

Fig. 4. Leiper Tourism Model 1990.

There are three basic elements of lepier's model:

1. Tourists: These are the major actors in the systems, tourism is a human experience, enjoyed, anticipated and remembered by many as some of the most important part of their lives (Cooper 1988).

2. Geographical Elements: Leiper identifies three geographical elements in the model:

$>$ Traveler generating region

$>$ Tourists destination region

$>$ Transit route

The traveler generating region is the place where tourism-markets generates this serves as a "push" to stimulate and motivate travel, here the tourists searched for information makes the booking and departs, the tourist destination region represents the sharpened end of tourism. The full impact of tourism are noticed and all administrative and planning strategies are implemented. According to (Leiper and Stear 1997) the destination too is the for tourism with range of special places distinguished from the everyday by their cultural, historic or natural significance. The "Pull" to visit destination is the "Hub" of the whole tourism system. (Leiper 1990) therefore concluded that the destination is the place where the most noticeable and dramatic consequences of the system occur. This transit route region is just the start period of the travel to reach the destination region this also includes places that may be visited en-route.

3. Tourism Industry: This is the third element of Leiper's model which includes the range of business and organization involved in delivering the tourism product. The model provides for the identification of various industrial sectors, for example travel agents and tour operators are mostly, found in the traveler generating region attractions and the hospitality industry are found in the destination region while transport sector is largely represented in the transit route region (Copper 1998). Each of these elements identified by Leiper's tourism system is said to interacts not only to deliver the tourism product but also, in terms of transactions and impacts the differing contexts within which tourism occurs. which is illustrates by Leiper's diagram: 


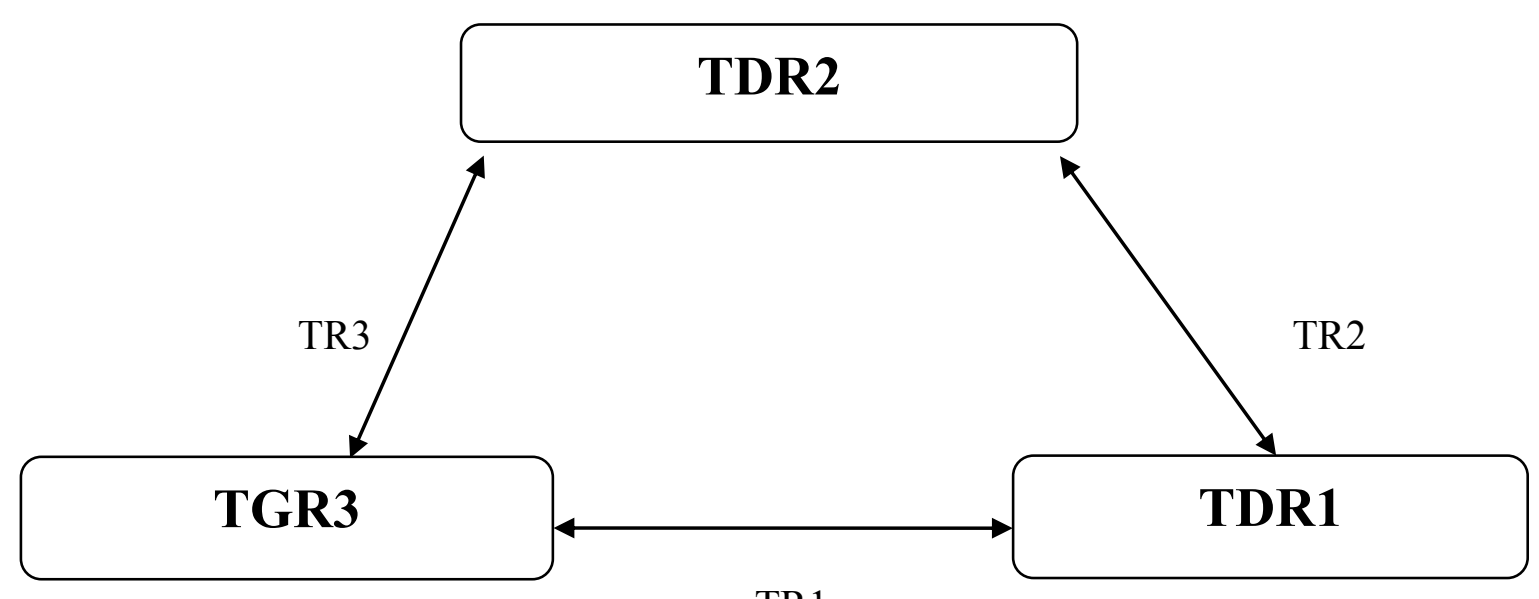

TR1

Fig. 5. Cooper 1988.

TGR : Travelers generating region

TR: Transit route

TDR: Tourists destination region

Leiper's model is also said to show clearly the contrast in the tourism industry which is best illustrated by examining two major elements of the model. Demand for tourism in the generating region is inherently, volatile, seasonal and irrational yet this demand is satisfied by a destination region where supply is fragmented and inflexible (Copper 1988). The major advantage of Leiper's model is the fact that it has general applicability and it is simple.

\section{DATA AND METHODS}

The study population concerns the population of tourist in Suntan Beach Badagry, Lagos Nigeria. which includes students, civil servants, self-employed, Factory workers, Traders. The study population includes tourists from the ages of 10-50 and above, amongst them can be found the adults, the aged and also young adults. These tourist can be involved in schooling or any employment position.

The sampling technique used is non-probabilistic, which is any sampling procedure, with no pre-assigned probability of including a particular unit into the sample. purposive 25 , which include the number of tourist, workers and the management, who would be key informants.

The research instrument is key informant interview method (K11) to be used with the Tourists(visitors), people on ground and the management of the Beach; it is a conversation between the interviewer and the respondent, with the purpose of eliciting certain information, this is possible through the following:

Cognition or understanding by the respondent of what is required

The respondent has knowledge of the required information

Motivation on the part of the respondents to answer the questions accurately . 
Data analysis involves the organization, rearrangement and presentation of data, in such a way, to the research questions it also brings about the accurate identification, description and explanation of the nature of interrelationship in the study population. The method of data analysis is qualitative method of analysis. Ethnographic summary is to be utilized, Quotes would be identified, using exact words that are descriptive, representative of the respondents' view and illustrate a particularly interesting perspective of one participant or respondent.

\section{RESULTS}

\section{1. Socio-demographic characteristic of respondents}

It was seen from the information collected, more than a quarter of the respondents' claimed to nineteen years old. half of the respondents were between the ages of twenty to twenty nine. this age group consists mostly, of students and workers. This data imply that young tourists visited more. The old age is just about four percentage.

From data collected, it was discovered that the tourists that were respondents, more than half were males, while quarter were females; this implies that are more males than females, who are visitors or tourists that care to come to the beach the time of survey. This implies that tourism has a link with sex, female with always go there with their opposite sex partner it may friends or family member females will not want to go alone.

From the findings, it was discovered that half of the respondents' were single, with a less than half were married, and other two who were divorced or widowed. Thus, this shows that bachelors and spinsters showed a higher preference for tourists center.

From the data collected, a quarter of the respondents have Islam as a religion, also there were a quarter tourists who were Christians, who two said practiced traditional religion. This show that majority of the tourists' either has Christianity or Islam, as a religion.

The data collected revealed that, all of the respondents had primary, and secondary education more than a quarter of the tourists had a tertiary education. There were five which had beyond B.sc. This implies that the tourists get education.

Of the respondents', in which more than quarter are student from tertiary institutions, while quarter are civil servant currently working, the self-employed is six percentages, factory workers amount to four percentage and just one percentage for others. This shows that the socio- economic is high from the point of student and civil servant are in most cases the best of the best in tourists.

\section{2. Socio-economic impacts of tourism}

Tourism like other industries affects the economy of an area especially the destination or receiving areas, many economies were said to be dependent upon an inflow of tourism. According to (Douglas 1988) that the flow of tourists between generating and receiving areas exerts effects which measured in four distinct ways namely;

1. Effect on income (E.O.I): Income is what accrued to the players in the business transaction income is generated from wages and salaries, interests, rent and profit. In tourism, the greatest proportion of income is said to be derived from wages and salaries paid to those working in jobs either directly, serving the needs of tourists or benefiting indirectly from the tourists' expenditure. Effect on income will be greater in those areas which receive large numbers of tourists, where visitors' tends to stay longer, where the destination attracts an up markets or more free-spend clientele and where there are many opportunities to spend, 
income in tourism is generated from interest from rent and profits such as :interest paid on loans to an airline in order to buy aircrafts, or rent paid to a landowner for a car part or campsite near the sea. we must also count taxation on tourism activities such as VAT on hotel bills or direct taxation, which some countries levy on tourism to raise additional public income (Douglas 1998). Attempts to measures the impact of tourism are always difficult because the spending by tourists and the spending by others in restaurants or shops. However, tourism contribute to the income of an area is enhanced by a phenomenon known as the Tourism Income Multipliers (T.I.M). This multiplier factor is the value by which tourist spending increased income of an economy.

2. Employment Effect (EE): Tourism generates employment in an economy, jobs are created in Travel agencies, Tour operator and other intermediates who supply tourists services in both the generating and destination areas. The bulk of employment in tourism is said to be in destination country with jobs ranging from hotel managers to deckchairs attendances from excursion booking clerk to cleaners employed in homes that are open to public or maintenance staff who will maintain the rides at leisure centers' or theme parts in the resort (Douglas 1988)employment effect is statistically measured by employment multipliers.

3. Balance of payment (B.O.P): Tourism may have a major influence on a country balance of payment. International tourists will buy tourists services in another country and these payments are noted in a country account as "invisible" it is important to understand that the outflow of money from a region being spent aboard counts as an "export" while the inflow of tourists' money spent in a region count as "export" the total value of receipts minus the total payments made during the year represents a country balance of payments on the tourism account. This is part of the country entire invisible balance which will include other service such as banking, insurance and transport.

4. Investment and Development (I.D): The need to attract tourists gears up investment and development in a region. As posited by (Douglas 1988) one factors helping to determine the success or otherwise of tourism in a region is the level of investment or otherwise. This often means that tourism cannot take off until the public sector is prepared to "kick start" the economy that is, to invest in risk capital in order to encourage tourism development. This might take the form of grants or low interest loans to private developers, or in some more centrally planned economies it may means that government itself builds and operate facilities such as hotels for tourists.

\section{3. Negative socio-economic impacts of tourism}

Result of the study shows that tourism may have a negative impact on the socioeconomic of the borders town, country and tourists due to the fact the production of tourist goods and services requires the commitments of resources which could otherwise be used for alternative purposes. For instance, the development of tourism resort may mean the migration of labour from rural to urban areas with its attendant for economics implications for both the rural and urban areas, the former looses a productive unit of labour whereas, the latter implying additional pressure on infrastructure, health etc.

Secondly, the use of capital resources in the development of tourism related establishment preclude their use for other forms of economic development this constitutes the "opportunity cost" of establishing tourism facilities. 
Finally, when tourism development substitutes one form of expenditure and economic activity for another. this is known as the "displacement effects" According to (Daniel 1988) this should be taken into account when studying the economic impact of tourism

\section{4. Restrictions and limitations}

This research was face with some of restricted and limited in certain aspect it was observed that most of the businessmen were not ready to part with information concerning their businesses. An important reference is the refusal of the beach operator to allow access to their business statement. Secondly, there is a complete famine of secondary data of this subject in the study area, this is supposed to have provided the necessary guide for whatever is presented in this report. Thirdly, the lack of application soft ware's in analyzing tourism statistics also limits what is needed to achieve.

\section{CONCLUSIONS}

The study concludes that tourism had been found to be a great player in the economy of an adequate endowed nations Lagos state in Nigeria is found to possess a huge potential tourism development. This study recommends a number of steps to be taken in order to meets the socio-economics of tourism development. The conclusion drawn from these new data shed much needed light on the tourism development in border state in Nigeria. The analyzed data includes personal interview from people in the tourism sector and together with other reports offers policy makers new insights that may help tourism and long term plan need over the next decade.

\section{Recommendations}

Government and private organizations most solicit and fund research on tourism and advocacy for research should include development explicitly.

Other steps that could be taken to address the problems include the following:

1. A national research programs, with specific and separate components should be aimed at tourism and development for national development.

2. The government should adopt a definite and sustainable tourism development policy.

3. Affordable and adequate entertainment facility should be provided at tourism centre.

4. There should be a holistic participation on the part of government to adopt a definite and sustainable tourism development policy.

5. Dissemination of information regarding Economic Impact Assessment (E.I.A) on tourism should be made available to researcher and partitional.

6. This sector should be opened up for people that knows the nitty-gritty of the tourism industry so that they will be allow to operate in the tourism industry. 


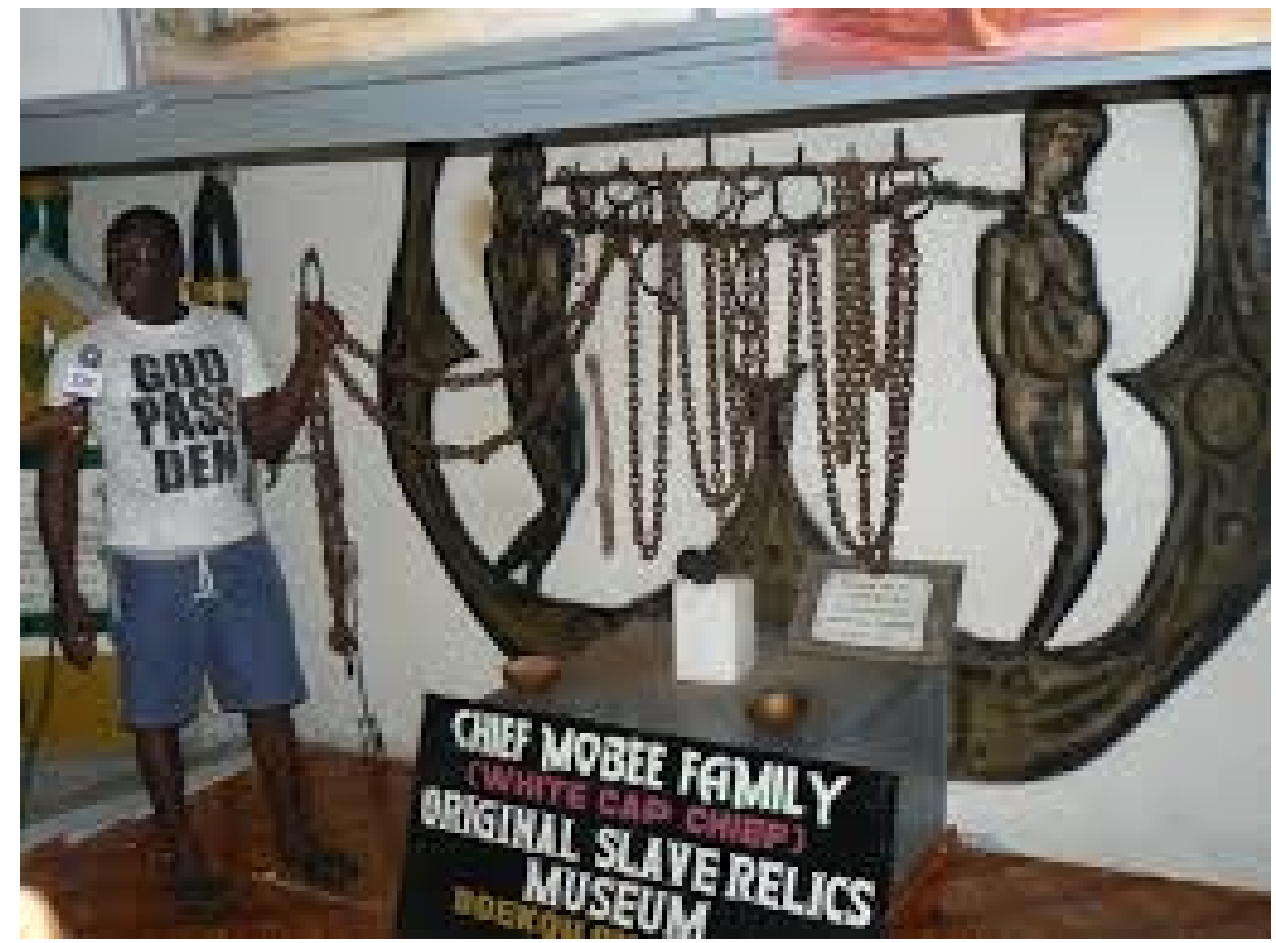

Fig. 6. Sahculs of slaves on display in private Museum in bagadry lagos.

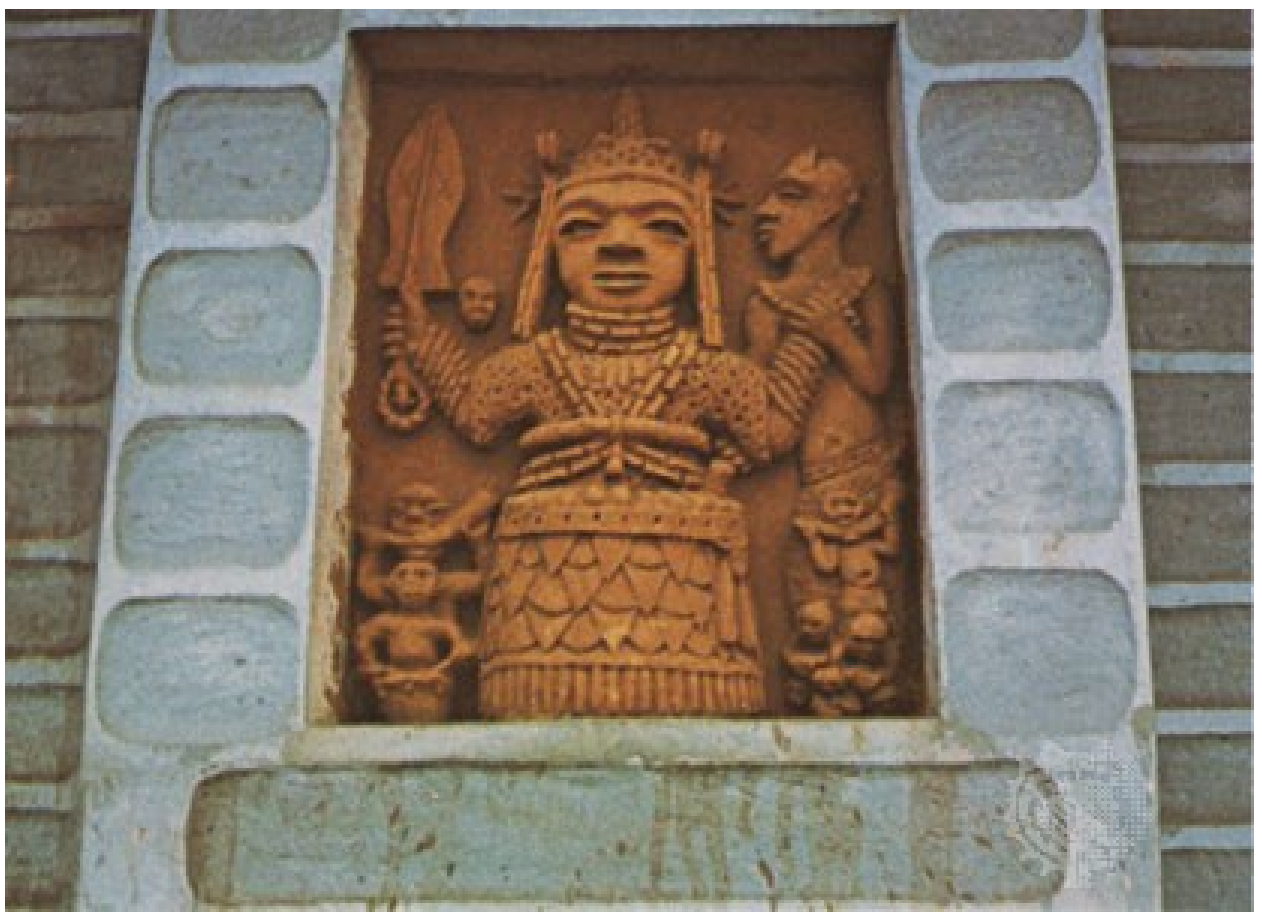

Fig. 7. Badagry was one of biggest slave routes in the early 1500 s. The site showcases what slaves went through before they were boarded on ships and taking out of. 


\section{References}

[1] Ackoff R. (1974). Redesigning the Future, New York: Wiley

[2] Coles T., Current Issues in Tourism 9(4) (2006) 292-319.

[3] Cooper C. (1998). "Tourism: Principles and Practice (2nd ed). Addison Wesley Longman. 20-25.

[4] David H. (1992). "International Tourism and the less Developed Countries: Balham Press London.

[5] Douglas P. (1998). Tourism Today: A Geographical Analysis (2nd ed.) U.S.A.

[6] Daniel, S (1999). Approaches to Estimating -Economic Impact of Tourism 840-890.

[7] Omotayo A. (1994). "The physical Fabric of Badagry -Development Discourse in Badagry", A History in Culture and Traditions of an Ancient City, 7-10.

[8] Hall C (2008). Tourism Planning, 2nd Harlow Pearson.

[9] Hall C., Tourism Recreation Research 35(3) (2010).

[10] Hall C., Jenkins J. (1995). Tourism public policy. London Routledge.

[11] Leiper N., Annals of Tourism Research 6(4) (1979) 390-404.

[12] Leiper N. (b), Annals of Tourism Research 7(2) (1980) 255-258.

[13] Leiper N., Annals of Tourism Research 8(1) (1981) 69-84.

[14] Leiper N., Annals of Tourism Research 10 (1983) 277-280.

[15] Leiper N. (1984). Tourism and leisure; the significance of tourism in the leisure spectrum. In Proceedings of the 12th New Zealand Geographical Society Conference, Hamilton: New Zealand Geographical Society, University of Waikato.

[16] Leiper N., Les Cahiers du Tourisme, Series B 44 (1985) 1-5.

[17] Smith S., Annals of Tourism Research 15 (1988) 179-190.

[18] Smith S., Annals of Tourism Research 18 (1991) 312-318. 